\title{
贵州草海湿地越冬黑颈鹤受食地与农耕地的空间关系 研究
}

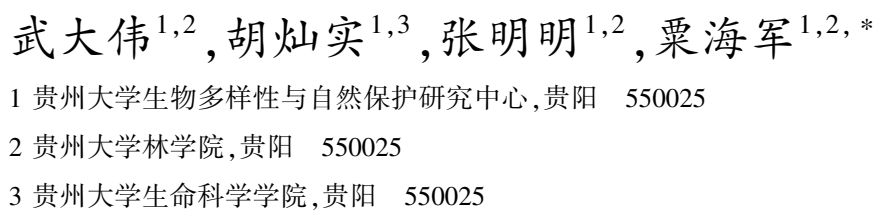

摘要: 贵州草海湿地是世界上最大的黑颈鹤东部种群越冬地之一。黑颈鹤在草海越冬期极其依赖农耕地受食存活,但当地人乌 争地冲突严重、受食地萎缩加剧。为此,运用空间点格局分析及缓冲区叠加分析, 探究黑颈鹤受食地与农耕地空间关联性, 并精 确确定出重点保护管理区域,结果表明: 1) 研究期间,两年共在草海湿地周边农地确定黑颈鹤受食点 216 处,其中家庭鹤受食地 99 处、集群鹤受食地 117 处,越冬种群中 $83 \%$ 的个体依赖农耕区受食;2) 区域尺度上,家庭鹤与集群鹤的受食点分布均为聚集 分布,但集群鹤受食点聚集程度较家庭鹤更高; 受食地与农耕地在空间聚类上呈正相关关系,并在 $3.2 \mathrm{~km}$ 距离尺度下聚类程度 最高;3) 基于空间关联性,通过缓冲区叠加分析,共确定最适宜的农地受食地 $53.74 \mathrm{~km}^{2}$,并划定 2 处重点核心保护区域及 2 处 次重核心保护区域范围。研究结果对于揭示区域尺度上黑颈鹤受食地与农耕地空间关系,指导保护管理者加强重点区域管理, 以及对区域土地利用规划和缓解人鸟争地矛盾,具有重要的理论与实践意义。

关键词 : 黑颈鹤; 受食地; 湿地周边农耕区; 种群空间分布格局; 贵州草海

\section{Spatial relevancy between foraging sites of overwintering Black-necked Cranes and farming lands in Caohai Wetland, Guizhou, China}

\author{
WU Dawei ${ }^{1,2}$, HU Canshi ${ }^{1,3}$, ZHANG Mingming ${ }^{1,2}$, SU Haijun ${ }^{1,2, *}$ \\ 1 Research Center for Biodiversity and Natural Conservation, Guizhou University, Guiyang 550025, China \\ 2 Forestry College, Guizhou University, Guiyang 550025, China \\ 3 College of Life Sciences, Guizhou University, Guiyang 550025, China
}

\begin{abstract}
The overwintering site is the key period that affects the population dynamics of migratory birds, and the quality of overwintering habitat plays an important role in the survival of the overwintering population. The Black-necked Crane is rated on the IUCN Red List of Threatened Species ( VU) and is also a national first-class protected wildlife in China. It is the only crane among the 15 known species that lives on the plateau all year round. Caohai Wetland is located in the Guizhou Plateau, and it is the largest overwintering site for the Black-necked Crane worldwide. During the wintering period in the Caohai Wetland, the survival of Black-necked Cranes (Grus nigricollis) heavily depends on the farmland due to their foraging activities. However, there is a very fierce competition between humankind and cranes for the local land, which has led to an increased shrinkage of foraging habitats. By using the spatial point pattern analysis and overlay analysis on the buffer zone, this research aims to explore the correlation between the foraging habitats of Black-necked Crane and farmland,

基金项目:国家自然科学基金项目(31860610); 贵州省科技重大专项(黔科合重大专项字 [2016]3022 号); 贵州省科技计划项目(黔科合平台人 才[2018]5781 号)

收稿日期:2019-11-27; 网络出版日期:2021-02-24

*通讯作者 Corresponding author.E-mail: hjsu@ gzu.edu.cn
\end{abstract}


as well as precisely determine the key protection and administrative areas. The results are as follows: 1) During the research period of two years (2016-2017, 2017 -2018), a total of 216 foraging habitats of the Black-necked Crane were discovered in the surrounding farmlands at the Caohai Wetland. Among these habitats, 99 were foraging habitats of family groups and 117 were foraging habitats of flocking groups. Importantly, about $83 \%$ of the cranes depended on the farmland for foraging during the wintering period. 2) In terms of regional scale, the foraging habitats distribution of family groups and flocking groups were both aggregated; however, the aggregation degree of flocking groups was higher than that of the family groups. The foraging habitats and farmland were positively correlated in terms of spatial clustering and demonstrated a maximum clustering degree at the distance of $3.2 \mathrm{~km} .3$ ) Based on the spatial association, via the overlay analysis on the buffer zone, a total of $53.74 \mathrm{~km}^{2}$ of farmlands were confirmed as the most suitable foraging habitats. Additionally, two primary core protection zonesand two secondary core protection zones were also delineated. The results have important theoretical and practical significance as they assist in revealing the spatial relationship between the foraging habitats and farmland at a regional scale, guiding the protection administrators to enhance administration on key zones and improving the regional land utilization planning and mitigation of land competition between humankind and cranes.

Key Words: Black-necked Crane; foraging sites; farming lands; spatial distribution pattern of the population; Caohai Wetland, Guizhou Province

从空间角度考察动物栖息地与人类土地利用关系,科学合理地确定重点保护区域, 是缓冲物种栖息地保 护与土地开发利用矛盾, 促进物种保育管理的重要方式 ${ }^{[1-2]}$ 。作为唯一一种终生生活在高原地区的鹤类 ${ }^{[3]}$, 黑颈鹤 (Grus nigricollis) 在我国繁殖地相对集中于西藏中西部、青海东部、四川北部等地。其中东部种群每年 秋季由四川北部、若尔盖湿地到达贵州草海和云南大山包等地越冬 ${ }^{[4-6]}$ 。在越冬地, 黑颈鹤常形成稳定的利 用人类耕地受食的习性 ${ }^{[7]}$, 越冬期间, 黑颈鹤日间 74\% 的时间是在农地上渡过的, 在西藏未翻耕的青稞和小 麦是其主要利用的农地食物, 而在海拔稍低的东部种群越冬湿地 (贵州草海、云南会泽、大山包等), 黑颈鹤主 要取食农耕地中的马铃薯 (Solanum tuberosum) 、玉米(Zea mays) 等残留作物 ${ }^{[7,8-12]}$ 。在贵州草海, $80 \%$ 的越冬 黑颈鹤白天在湿地周边的农耕区受食, 夜晚则全部回到湿地涉水夜栖 ${ }^{[3,13]}$ 。因此, 草海湿地周边农耕地及其 土地利用方式的保护, 对于黑颈鹤的越冬存活与栖息地保护具有重要意义。然而, 由于草海湿地毗邻威宁县 城且区域内村寨居民众多, 人鸟争地矛盾十分突出, 近年来由于城市扩张及农耕方式改变, 原有的传统农耕区 不断萎缩,使得黑颈鹤的越冬存活受到极大影响 ${ }^{[14]}$ 。

从土地利用的空间关系角度探讨鹤类保护与人类冲突已有较多研究。彭婉婷等在云南大山包利用实地 调查与遥感土地利用影像结合, 发现黑颈鹤冬季依赖农田受食, 揭示出黑颈鹤存在因迁徙而导致食物短缺的 潜在风险, 表明生态补偿可作为改善野生动物栖息地的有效策略 ${ }^{[15]}$; 刘伶等通过历史上苏北地区丹顶鹤越冬 分布的数据及遥感影像结合分析, 得出苏北地区丹顶鹤越冬种群数量及栖息地分布变化与周边土地利用方式 及人为干扰有关 ${ }^{[16]}$; 彭文娟等通过多年卫星遥感影像分析得出升金湖由于土地利用方式的变化, 在湿地越冬 的水鸟数量也发生了巨大变化,白鹤、白枕鹤等鹤类已濒临绝迹 ${ }^{[17]}$ 。可见土地地利用方式对鹤类栖息有着重 要影响。然而, 以往的研究多集中于利用生态位模型如最大熵模型、逻辑斯蒂模型等进行生境适宜性评 价 ${ }^{[18-19]}$, 但该类模型大都只是物种潜在分布的简单估计,对于土地利用空间格局因素与物种栖息地利用的互 作影响分析不足 ${ }^{[20-21]}$, 因此研究结果对于准确指导土地利用与栖息地保护的成效、缓解人鸟争地矛盾也较为 有限。鹤类对栖息地具有高度的选择性,而这种选择性与农耕地空间格局究竟有何关系呢? 回答这一问题即 有利于进一步揭示鹤类对人为干扰条件下行为适应,也有利于直接指导在人鸟冲突严重情况下的栖息地保护 管理。

草海湿地周边的农耕区域面积有限, 且随着开发力度的加大, 域内机耕道路纵横, 大棚等新兴农业设施不 断涌现, 村庄交错与城市化扩张等因素带来土地利用的空间格局剧烈变化,黑颈鹤在农耕区的受食地选择需 
要考虑和权衡多种影响因素 ${ }^{[14,22-23]}$ 。因此,精确地掌握黑颈鹤选择受食地的规律性,确定保护管理的重点和 核心区域有利于缓和人鸟争地冲突, 集中力量做好重点区域的保护。为此, 为准确分析黑颈鹤对受食地点的 选择与农耕地间是否存在一定的空间关联性? 以及这种关联性如何指导准确的栖息地保护管理,本文通过遥 感卫星影像结合实地调查利用点格局及缓冲区叠加分析方法, 对这些问题进行了研究, 以期为黑颈鹤的保护 管理及其他类似的生态问题提供科学参考,具体报导如下。

\section{1 研究区域及方法}

\section{1 研究区域概况}

草海湿地 (草海国家级自然保护区, N26 $47^{\prime}-26^{\circ} 52^{\prime}, \mathrm{E} 104^{\circ} 10^{\prime}-104^{\circ} 20^{\prime}$ ) 位于贵州威宁县城南, 地处云 贵高原乌蒙山腹地, 是贵州最大的天然高原淡水湖泊, 其生态系统结构和功能完整, 是我国高原高寒湿地生态 系统的典型代表, 也是我国西南地区迁徙水禽的重要越冬地和停歇地 ${ }^{[24]}$ 。保护区总面积 $120 \mathrm{~km}^{2}$, 草海湖正 常水域面积约 $25 \mathrm{~km}^{2}$, 正常水位 $2171.70 \mathrm{~m}$, 最大水深 $5.00 \mathrm{~m}$, 湿地属亚热带高原季风气候, 平均气温 $10.9^{\circ} \mathrm{C}$, 最冷月 (1 月) 平均气温 $2.1^{\circ} \mathrm{C}$, 最暖月 $\left(7\right.$ 月) 平均气温 $17.7^{\circ} \mathrm{C}$ 。湿地水草丰茂,物种丰富, 已记录鸟类 246 种, 其中水鸟逾 80 种, 冬季栖息数量近 8 万只。由于草海湿地毗邻县城, 且沉积型土地肥沃, 周边区域内居住着 18 个行政村约 7 万余人, 人口密度达 392 人 $\mathrm{km}^{2}$, 区域内耕地面积 $4200 \mathrm{hm}^{2}$,约占全保护区面积的 $43 \%{ }^{[14,25]}$, 但草海湿地周边盆地内耕地面积仅 $704 \mathrm{hm}^{2}$, 随着城市扩张、城镇化建设及人口增长, 近 20 余年, 周边耕地面积减少了近 $10.57 \%$ [26-27]。当地主要以第一产业为主,农牧产业发达,农地面积广阔, 且种植的马 铃薯等作物是越冬黑颈鹤受食的倾向选择食物 ${ }^{[14]}$ 。但由于城市扩张、人口增长, 产业转型及新型耕作方式的 出现等原因, 导致人鸟争地情况日益加深。严重影响黑颈鹤等越冬水鸟的生存 ${ }^{[14]}$ 。

\section{2 研究方法}

黑颈鹤在草海越冬期平均为 $153 \mathrm{~d}$ 左右 $(130-170 \mathrm{~d})^{[26]}$, 从每年 10 月开始陆续到达草海, 次年 3 月左右 离开 ${ }^{[3]}$ 。在草海越冬期间, 共发现 7 个夜栖地点, 分布在草海湖湖畔 ${ }^{[3]}$, 根据观测每天日出前, 鹤会飞向周边 受食地受食,傍晚回到栖息地休息。2015 年冬约 2000 余只黑颈鹤在草海越冬 ${ }^{[14]}$,其中约 $80 \%$ 的鹤会飞向距 离夜栖地更远的农地内受食,仅少部分会留在夜栖地周边受食 ${ }^{[23]}$ 。大部分黑颈鹤夜间栖息在西部和西南部 的几个夜栖地中,其中以温家屯、阳关山最多,其余零散分布于其他夜栖地。而其他文献中记载的胡叶林夜栖 地 ${ }^{[10]}$, 由于水位上升、村镇干扰等原因,在此休息的黑颈鹤已急剧减少。

为此,本研究主要采用点格局函数来分析越冬黑颈鹤受食地的空间分布格局,及受食地与耕地之间的空 间关联。步骤为: (1) 通过单变量 L 函数来确定家庭鹤、集群鹤两种类型的鹤群的受食地空间格局。(2)采用 双变量 $\mathrm{L}$ 函数分析受食地与耕地之间的空间关联。得到两者间聚类程度最高的距离,用此距离设置缓冲区确 定最适宜的潜在农耕地受食地的农地范围。(3) 在所得到的最适宜的潜在农耕地受食地农地范围内,结合受 食地空间格局与草海当地土地利用情况,确定不同重要保护程度的栖息地准确范围。

\subsection{1 土地利用分类及绘图}

本研究的土地利用分类按照中国《土地利用现状分类》(GB/T 21010-2017) ${ }^{[28]}$, 结合草海湿地及其周边 实际情况, 分为耕地及其他四类非受食地利用类型 (林地、水域、建设用地、草甸滩涂) 共五类。以 2017 年 Landsat OLI 数据为基础数据源, 在 ERDAS 2010 软件中以 SPOT 正射影像为参考,进行数据进行校正, 误差控 制在 0.5 个像元以内, 可以满足研究精度要求。将坐标统一到 CGCS 2000 投影坐标系下, 采用掩膜提取的方 法裁剪得到研究区域影像图。最后使用 ArcGIS 10.3.0 进行人工目视解译, 在解译过程中结合实地观测进行 修正,最终得到 2017 年草海周边土地利用类型图 (图 1)。

\subsection{2 越冬受食地具体位点的确定}

野外调查于 $2016-2017 、 2017$ - 2018 两个冬季进行, 总计调查 $90 \mathrm{~d}$ 。每个冬季调查 3 次, 每次调查约 15 $\mathrm{d}$,调查选择晴朗无风的天气进行, 调查时间为 8:00-17:00。根据前期预调查情况, 在研究区域内利用 


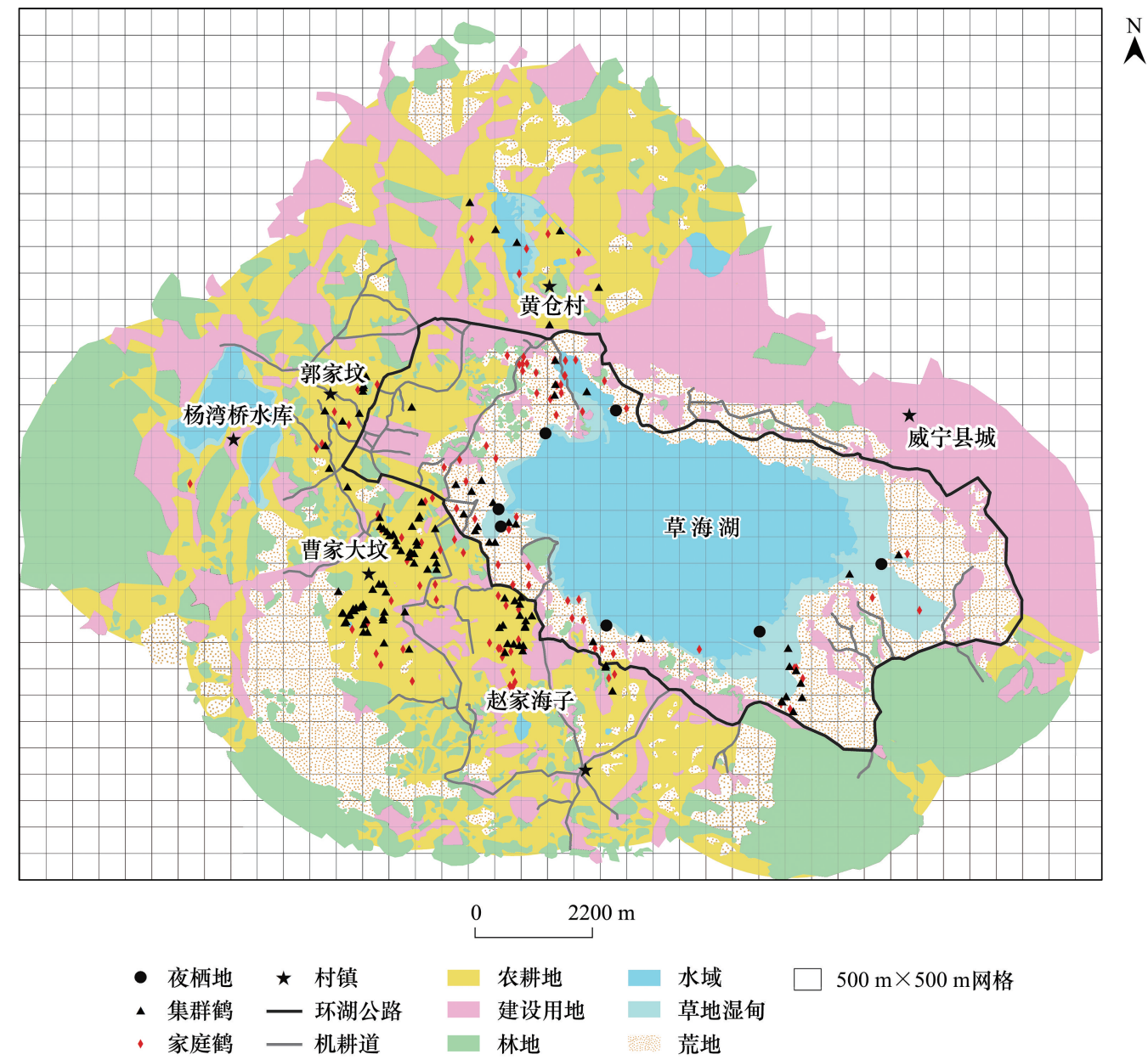

图 1 贵州草海湿地土地利用类型及黑颈鹤受食地与夜栖地分布

Fig.1 Land-use types and distribution of foraging sites of Black-necked cranes in the Caohai wetland, Guizhou province, China

ArcGIS 10.3.0 绘制 $500 \mathrm{~m} \times 500 \mathrm{~m}$ 的调查范围格网,逐个排查格网内是否有受食地 (图 1)。发现受食地后借助 单筒望远镜 (SWAROVSKI -STS65 HD,倍率 20-60 X) 在网格内制高点远距离观察黑颈鹤受食行为,若该地 点在无干扰下被连续受食利用 $15 \mathrm{~min}$ 以上,定位暂时记录该地为一处受食地。每次调查期重复调查 3-5 次,若在调查期中 2 次以上均发现同一地点有黑颈鹤受食,则确定记录此地为一处受食地。结合前人研究,本 研究将受食鹤群统一划分为家庭鹤和集群鹤两种类型, 家庭鹤: 由小于等于 2 只幼鹤和 2 只成鹤组成; 集群 鹤: 由大于等于 2 只成鹤组成 ${ }^{[29]}$ 。调查共确定家庭鹤受食地 99 处,集群鹤受食地 117 处。家庭鹤若连续两 年均确定某一地点为受食地, 则只记录一次, 若在此地受食的为集群鹤,则记录两年鹤数量平均值。

\subsection{3 空间分析}

运用点格局分析 (Point Pattern Analysis) ${ }^{[30]}$ 检验黑颈鹤越冬受食地空间分布模式及受食地和农耕地之间 的空间格局关系。点格局分析最初由 Ripley ${ }^{[31]}$ 提出, 后经过 Diggle ${ }^{[32]}$ 等人发展。现已被广泛应用于种群空 间格局及种内和种间的空间关系分析中。点格局函数通过一系列连续距离上的物种分布来量化完全映射点

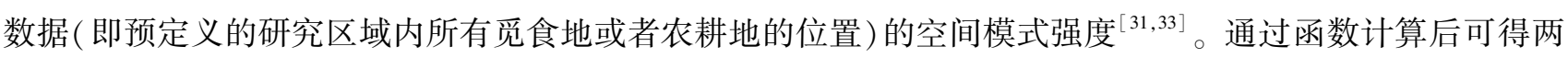
个数据, 分别是观测值和预期值。将距离内的点观测值与空间随机分布的预期值进行比较, 确定其空间聚集 或空间扩散的程度。如果特定距离的观测值大于预期值,则与该距离 (分析尺度) 的随机分布相比,该分布的 聚类程度更高。如果观测值小于预期值，则与该距离的随机分布相比，该分布的离散程度更高。

本研究设定采用点格局函数的线性模式 $L$-函数来进行分析 ${ }^{[33]}$, 其数学公式为: 


$$
L(r)=\sqrt{\frac{A \sum_{i=1}^{n} \sum_{j=1, i \neq j}^{n} k(i, j)}{\pi N(N-1)}}
$$

式中, $A$ 是研究区的范围大小, $N$ 即是点的数量, $r$ 为距离尺度大小, 而 $k(i, j)$ 则代表权重 ${ }^{[34]}$, 权重 $k(i, j)$ 取决 于 $i$ 和 $j$ 的距离,在 0 和 1 之间变化。当距离不大于 $r$ 时,取 1 。当距离大于 $r$ 时, 取 0 。

如图 2 所示, 将农耕地栅格数据转换为点数据后提取 $X Y$ 值, 提取集群鹤、家庭鹤受食地分布点的 $X Y$ 值。 导人 Programita Febrero 2014 点格局分析软件, 选择蒙特卡洛模拟 99 次, 采用 CER 零模型, 步长设置 $200 \mathrm{~m}$ 。 单一由鹤受食地点数据导人软件得到单变量 $L$-函数, 用以确定受食地空间格局。高于置信区间上包络线的 $L(r)$ 的观测值表示距离 $r$ 处为聚集分布, 低于置信区间下包络线的 $L(r)$ 的观测值表示距离 $r$ 处为规则分布; 将鹤受食地点数据与农耕地点数据整合, 设置为双变量后导人软件得到双变量 $L$-函数, 用以确定受食地与农 耕地之间空间关联, 高于置信区间上包络线的 $L(r)$ 的观测值表示距离 $r$ 处受食地和农耕地呈正相关, 为正关 联, 低于置信区间下包络线的 $L(r)$ 的观测值表示距离 $r$ 处受食地和农耕地呈负相关, 为负关联, 处于置信区 间上下包络线之间的 $L(r)$ 的观测值表示距离 $r$ 处无关联。由于所有受食地均在研究区域内, 因此无需边缘 校正。

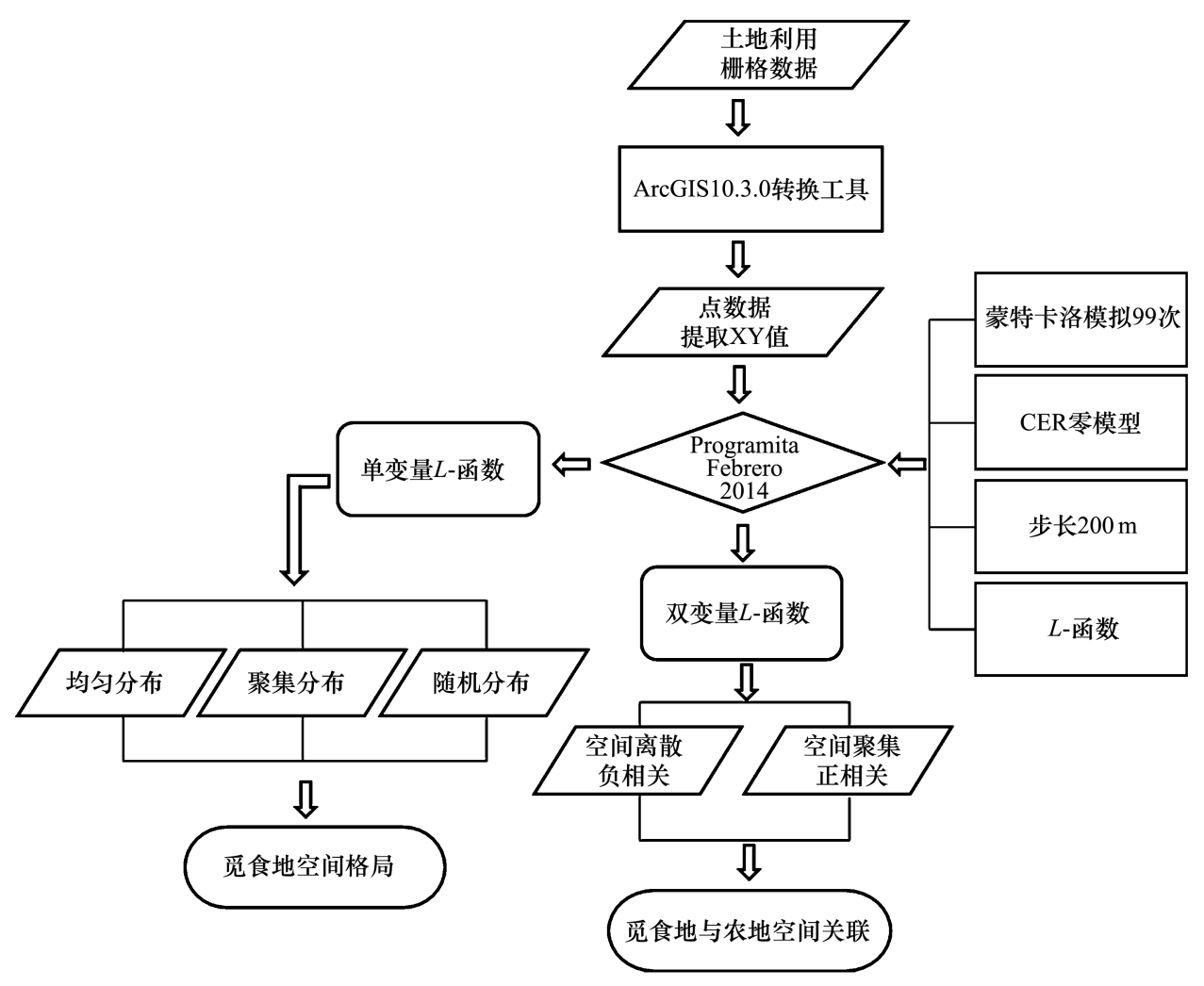

图 2 研究技术路线图

Fig.2 Research roadmap of this study

\subsection{4 缓冲区叠加分析}

若通过点格局函数分析得到受食地与农耕地聚类的距离, 则表明现有的受食地与农耕地在该距离上是正 相关, 即黑颈鹤更倾向于在以现有受食地为圆心, 以聚类距离为半径的圆的农耕地上受食。将聚类程度最高 的距离设为 $R$, 以 $R$ 为半径, 以现有已知的全部鹤类受食地为圆心, 则得到受食地与农耕地之间空间正关联最 强的范围, 以此距离设置缓冲区, 将得到受食地分布理论最适宜范围。采用叠加分析中的擦除模式, 将最适宜 范围中不适合鹤类进行受食的地点剔除, 最终划定草海湿地周边农耕区中越冬黑颈鹤受食地分布的准确 范围。 
通过受食地空间格局和缓冲区叠加分析,在当前此区域农耕地建设项目兴起、农地萎缩、人鸟争地冲突加 剧的情况下,为提高保护效率,根据适宜程度,将现有的受食地聚集的区域划分为重点核心保护区域和次重核 心保护区域。根据草海当地农地情况,重点核心保护区域主要包括现有的受食地集中的农地;次重核心保护 区域主要为距离现有受食地较近,相对靠近夜栖地且受干扰较低的大面积连续农地。

\section{2 研究结果}

2.1 草海越冬黑颈鹤受食地分布及分布格局

如表 1 所示, 研究期间在农地内受食的越冬黑颈鹤其数量达到了整个草海越冬黑颈鹤的 80\%以上。

表 1 研究期间草海湿地越冬黑颈鹤受食地与种群数量

Table 1 Numbers of foraging sites and population size of Black-necked crane during the periods of this study

\begin{tabular}{|c|c|c|c|c|c|c|c|c|c|c|}
\hline $\begin{array}{l}\text { 类型 } \\
\text { Type }\end{array}$ & $\begin{array}{c}\text { 受食地数量 } \\
\text { Number of } \\
\text { foraging } \\
\text { sites }\end{array}$ & $\begin{array}{c}\text { 种群数量 } \\
\text { Total of } \\
\text { wintering } \\
\text { cranes }\end{array}$ & $\begin{array}{l}\text { 农地内受 } \\
\text { 食数量 } \\
\text { Total of } \\
\text { foraging } \\
\text { cranes in } \\
\text { farmland }\end{array}$ & $\begin{array}{c}\text { 受食地鹤 } \\
\text { 数量最小值 } \\
\text { Min per } \\
\text { each } \\
\text { foraging } \\
\text { site }\end{array}$ & $\begin{array}{c}\text { 受食地鹤 } \\
\text { 数量最大值 } \\
\text { Max per } \\
\text { each } \\
\text { foraging } \\
\text { site }\end{array}$ & $\begin{array}{c}\text { 觅食地鹤 } \\
\text { 平均数量 } \\
\text { Mean }\end{array}$ & $\begin{array}{l}\text { 标准差 } \\
\text { Standard } \\
\text { deviation }\end{array}$ & $\begin{array}{c}\text { 方差 } \\
\text { Variance }\end{array}$ & $\begin{array}{c}\text { 距离草海湖 } \\
\text { 最小距离 } \\
\text { Distance } \\
\text { from Lake } \\
\quad(\text { min })\end{array}$ & $\begin{array}{c}\text { 距离草海湖 } \\
\text { 最大距离 } \\
\text { Distance } \\
\text { from Lake } \\
\text { (max) }\end{array}$ \\
\hline 家庭鹤 Family crane & 99 & 341 & 149 & 3 & 4 & 3.44 & 0.5 & 0.25 & 0.35 & 6.74 \\
\hline 集群鹤 Non-family crane & 117 & 2207 & 1991 & 2 & 246 & 18.88 & 34.48 & 1188.76 & 0.63 & 5.38 \\
\hline
\end{tabular}

由单变量 $L$-函数可见,家庭鹤和集群鹤的越冬受食地均为聚集分布。其中家庭鹤受食地随距离增加聚 集程度越大;集群鹤受食地在 $3.2 \mathrm{~km}$ 处聚集程度最大,之后随距离增加, 聚集程度降低( 见图 3)。

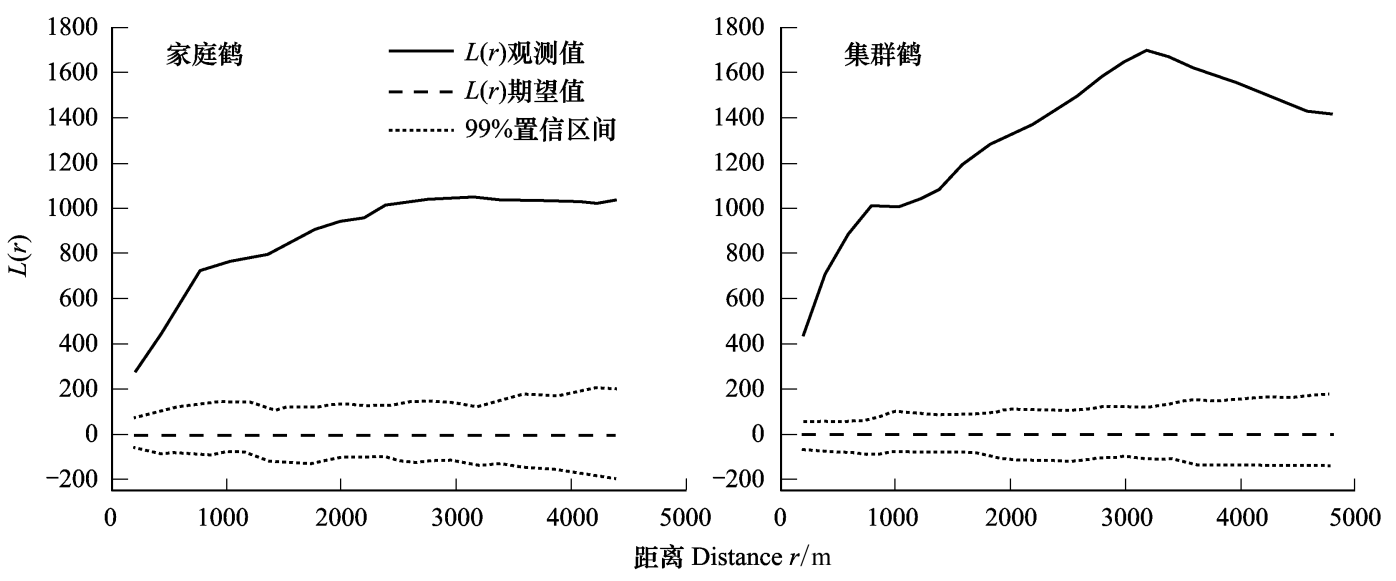

图 3 -元 $L$-函数与距离 $\mathbf{R}$ 的关系图, 用以表示鹤受食地的空间格局

Fig.3 The relationship between the $L$-function and the distance $r$ used to represent the spatial pattern of the crane habitat

实线为 $L(r)$ 观测值, 线虚线为 $L(r)$ 期望值; 点虚线为 $99 \%$ 置信区间

2.2 黑颈鹤受食地与农耕地空间分布格局关联性

双变量 L-函数中, 越冬期受食地和农耕地的函数观测值均位于置信区间上包络线之上, 表明均为正相 关, 黑颈鹤越冬期受食地对农耕地正面依赖, 具有强烈的空间聚集性特征, 在 $3.2 \mathrm{~km}$ 相关度最强, $L(r)=2.45$ (图 4)。

2.3 基于空间关联性的黑颈鹤重点农耕区受食地区域划定

对已知的家庭鹤和集群鹤受食地点进行半径为 $3.2 \mathrm{~km}$ 的缓冲区分析,得到基于黑颈鹤当前分布格局与 农耕地间空间格局关系的最适受食地范围。通过叠加分析, 将最适范围中不适宜黑颈鹤越冬受食的建设用 
地、林地等非耕地地类擦除,从而得到最适宜农耕受食 地分布的农耕地 (图 5,图 6), 面积总共有 $5374 \mathrm{hm}^{2}$ 。

因此划定重点核心保护区域主要有草海湖西南部 的曹家大坟周边及郭家坟周边区域 (图 6 黑圈)。次重 核心保护区域主要为锁黄仓区域及赵家海子周边 (图 6 绿圈)。此外其他农地由于暂未发现受食地, 且没有连 片分布,所以其保护力度可相对较低。

\section{3 讨论与结论}

\section{1 越冬黑颈鹤受食种群空间格局}

种群空间格局是种群内个体的空间分布方式或配 置特点, 是可以定量化描述的基本特征之一,也是种群 生态特性、种内种间关系及生物与环境相互作用等综合 作用的结果 ${ }^{[35-37]}$ 。黑颈鹤主要以家庭鹤和集群鹤两种 模式越冬,其中家庭鹤多由 2 只亲鹤和 1-2 只幼鹤组 成,其在越冬期间仍有较强的领域性,且领域面积较 $大^{[29,38]}$, 云南纳帕海的 1 个家庭鹤领域面积可达 2.62

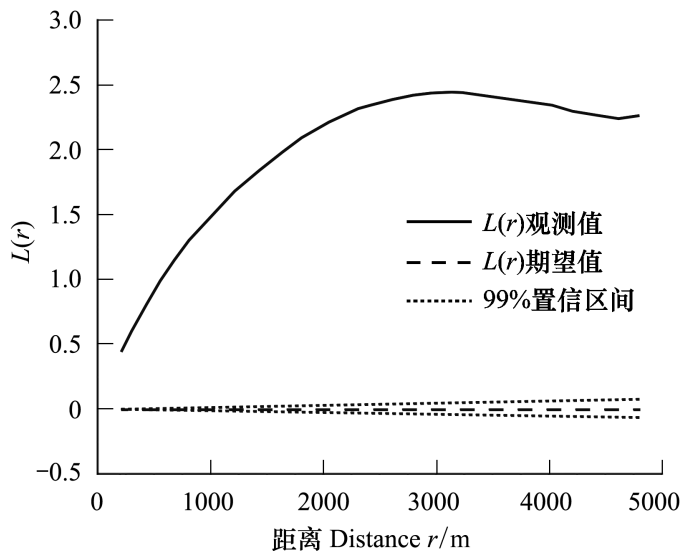

图 4 一元 $L$-函数与距离 $r$ 的关系图, 用以表示鹤受食地与农耕 地之间的空间关联

Fig.4 The relationship between the unary $L$-function and the distance $r$ used to represent the spatial correlation between the crane habitat and the agricultural land

实线为 $L(r)$ 观测值, 线虚线为 $L(r)$ 期望值; 点虚线为 $99 \%$ 置信 区间

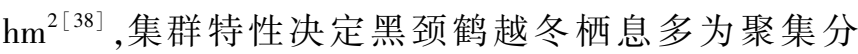

布 ${ }^{[39]}$,但以往的研究均没有完全准确定位黑颈鹤的受食地点,并对其聚集的空间格局进行分析。本研究将草 海湿地黑颈鹤越冬的受食地均进行了准确定位 (图 1), $L$-函数结果表明,草海越冬的黑颈鹤不论是家庭鹤还 是集群鹤，其值均高于置信区间上包络线的 $L(r)$ 的观测值，说明受食地空间格局均为聚集分布。但家庭鹤受 食地随距离增加聚集程度越大, 集群鹤受食地则在 $3.2 \mathrm{~km}$ 处聚集程度最大, 之后随距离增加, 聚集程度降低。

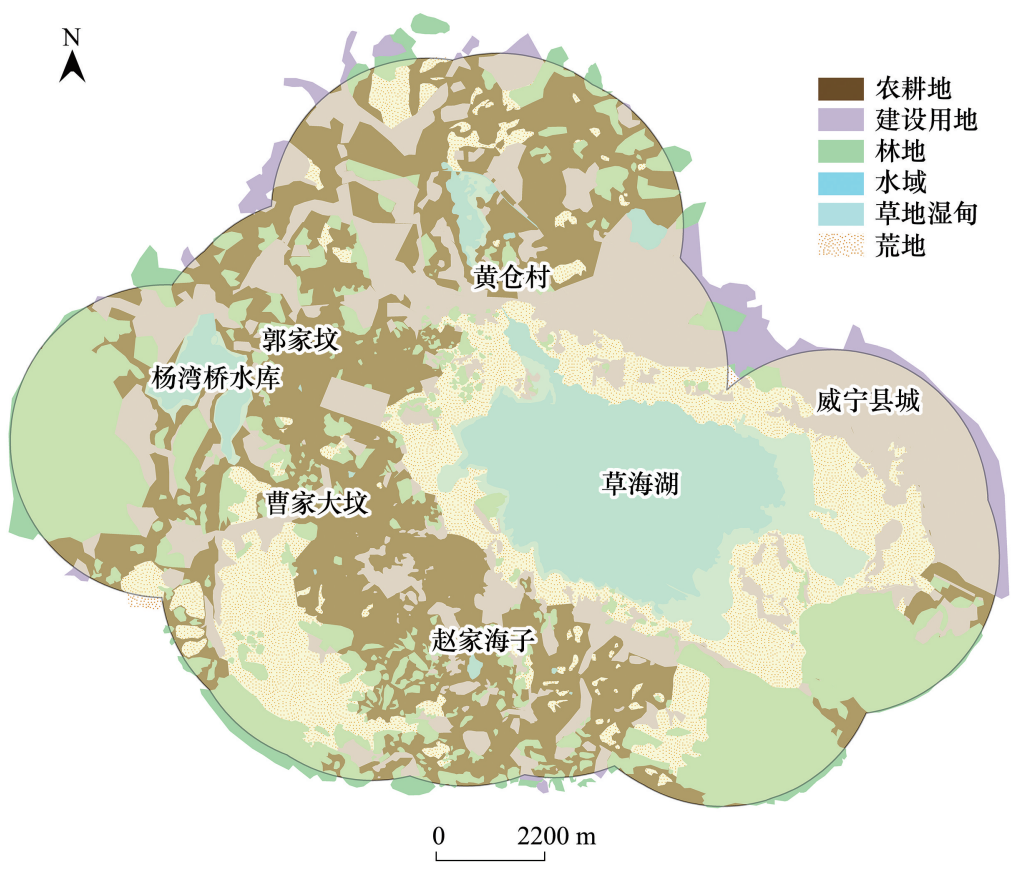

图 5 对所有受食地添加缓冲区后所覆盖的范围

Fig.5 The coverage after adding a buffer to all foraging sites 


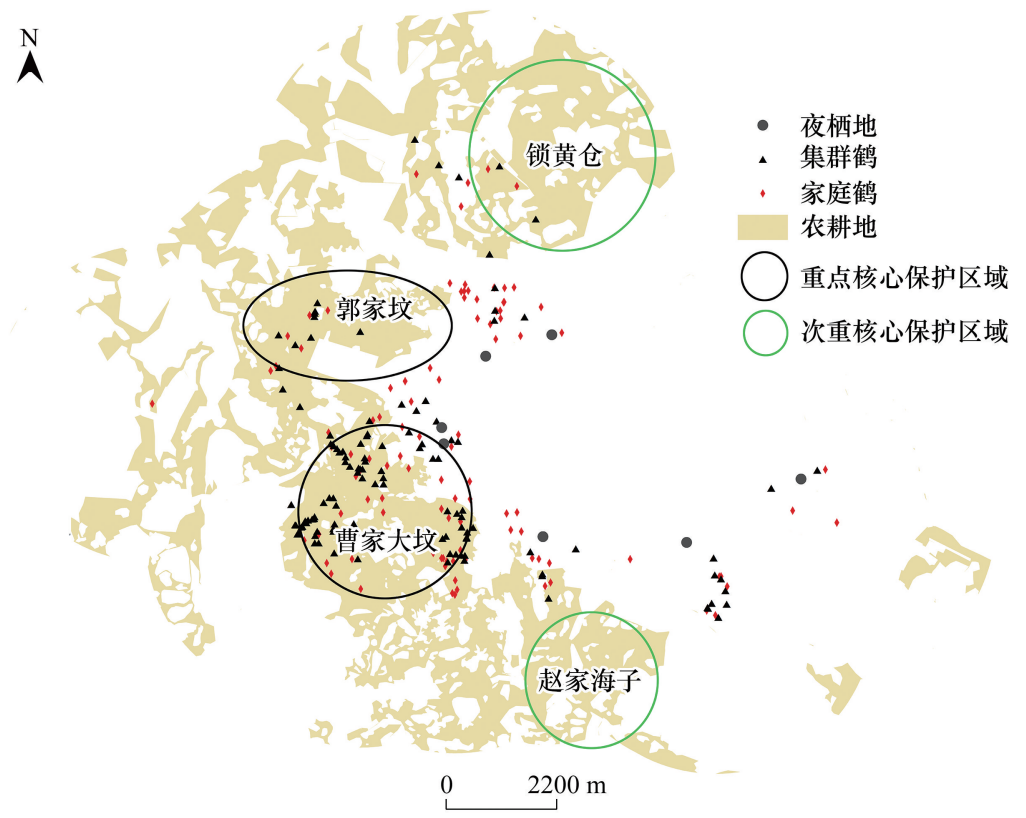

图 6 叠加分析后农地范围及保护区域

Fig.6 The zones of protection in farmland area to wintering Black-necked crane determined by superposition analysis

这可能与草海两种类型鹤的受食地分布特征有关: 家庭鹤仅占越冬种群的 $13.4 \%$ (表 1), 这一类型鹤受食地 分布较散, 其领域性及利用的忠诚度 (多年越冬均利用同一地点) 较高 ${ }^{[13]}$, 仅 $43.7 \%$ 的家庭鹤利用农耕地作为 受食地, 而集群鹤则 $90 \%$ 以上均利用农耕地作为受食地, 而草海北部紧邻威宁县城, 东部亦为城镇扩张区, 从 而导致东部农田面积相应减少,仅西部和南部距离草海湖较远的地块中有大面积农耕地(图 1)。这也使得在 西部和西南部的受食地聚集明显。同时, 由于近期退耕还湿地等政策使得水位上涨, 使得黑颈鹤的湖边原始 受食地选择减少 ${ }^{[14]}$ 。使得受食地更多的向远离湖滨的农地内聚集, 因此家庭鹤受食地虽也为聚集分布但聚 集程度远小于集群鹤。与其他越冬地相比, 草海当地人为干扰因素更强烈 ${ }^{[14]}$, 而大山包和会泽等东部种群越 冬地大多分布在无人区或人为干扰相对较低的区域 ${ }^{[40]}$, 分布格局则有可能不同。

\section{2 草海越冬黑颈鹤受食地与农耕地之间的空间关联}

人为活动干扰容易造成鹤类越冬栖息空间压力,但人为耕作的农地却也成为许多鹤类越冬的重要受食生 境 ${ }^{[40-41]}$ 。本研究也表明, 越冬黑颈鹤受食地与农耕地成正相关, 这种关联表明, 受食地分布格局可能是对农 耕地分布的一种反应。根据实际调查, 2014 年修建的环湖公路距离草海湖平均距离为 $1 \mathrm{~km}$, 受食地大多聚集 分布在距离草海湖 $5 \mathrm{~km}$ 范围内, 野外调查发现的黑颈鹤最远的一处受食地距离最近的夜栖地为 $6.74 \mathrm{~km}$ (表 1), 近两年来环湖公路内耕地大多已退耕还湖, 草海周边现有的大面积农地主要分布在环湖路外距离草 海 $1 \mathrm{~km}-6 \mathrm{~km}$ 内, 而农地周边仍分布有大量村落等建设用地 (图 1), 因此而导致函数在 $3.2 \mathrm{~km}$ 左右距离内 受食地数量密度最大, 使得受食地与农地在 $3.2 \mathrm{~km}$ 处关联性最强。

草海黑颈鹤受食地与农耕地的这一空间关联性可能与当前黑颈鹤在草海食物利用和对农耕地受食依赖 变化密切相关。20 多年前的研究表明, 当时的草海越冬黑颈鹤受食地选择中, 莎草草甸利用率最高, 农地利 用率较低, 食性分析也显示栽培作物占比不足 $3 \%$, 农地对草海越冬黑颈鹤吸引程度并不高 ${ }^{[10-11]}$ 。而本研究 期却发现黑颈鹤大量依赖农耕地受食 (表 1), 也可能也近些年湖滨带的环境变化有关系。近 20 年来,城镇扩 张、退耕还湖、水位抬升、保育建设工程等措施反复上演, 使得草海湖周边原有的自然生境退化, 景观格局变化 大、速率高, 周边的莎草草甸为主的滩涂面积减少, 主要的自然食源减少, 2001年滩涂面积为 $372 \mathrm{hm}^{2}, 2015$ 年 降至 $255 \mathrm{hm}^{2[26,42]}$, 另一方面, 2001 年以来, 整个草海区域农耕地大量丧失, 尤其是作为原受食地的东面 
(鸭子塘) 和东南面原有分布的大面积农地区域已被开发,农耕地丧失殆尽,仅余西南面和西面部分耕地 ${ }^{[42]}$ 。 威宁现有农耕地大量种植富含淀粉的马铃著, 种植面积占比达 $48.95 \%{ }^{[23,43]}$, 而越冬黑颈鹤喜食富含淀粉的 植物块状根茎 ${ }^{[11]}$, 因此耕地逐渐取代了湖滨地带自然生长的莎草草甸成为主要的越冬黑颈鹤受食地, 越冬黑 颈鹤更倾向于在农耕地中受食,从而使得受食地在空间上与农耕地联系更紧密。

3.3 草海周边农耕区越冬黑颈鹤重点受食地的划分

基于上述空间关系结果,通过建立缓冲区而得到草海越冬黑颈鹤潜在的可能作为受食地的农耕地,面积 达到 $5374 \mathrm{hm}^{2}$ (图 5、6)。这一面积相对于整个湿地自然保护区内的农耕面积而言,仍然较大,保护管理的指 导意义不明显。在此区域内,部分建设用地及其他类型的土地利用导致耕地相对破碎化,而更多的耕地由于 距离人居区较近, 干扰较大, 因此并不完全适合作为黑颈鹤受食地 (图 5)。为此, 通过受食地空间格局和缓冲 区叠加分析,擦除非农耕地的生境斑块后,将现有的受食地聚集的区域划分为重点核心保护区域和次重核心 保护区域, 两等级区域面积缩小至 $2200 \mathrm{hm}^{2}$ 。重点核心保护区域主要包括曹家大坟和郭家坟区域, 这一区域 受食地分布密集, 与农耕地关联性大, 建议保护管理部门重点关注这一区域的农耕地保全, 注重保留传统耕作 方式、耕作种类和数量、禁止农药施用等管理;次重核心保护区域主要包括锁黄仓、赵家海子等区域,这些区域 分布有少量受食地, 靠近夜栖地且连片分布农地面积较大, 受到的干扰较少, 在相同条件下更有可能会成为重 点核心保护区域受食地选择的替补。从总体上讲,草海整体的土地利用空间规划,都需要关注外围农耕区域 中重点核心保护区域、次重核心保护区域的土地利用性质与方式,除重视湖滨带湿地生态系统恢复重建外,外 围农耕区涉及人鸟冲突更为严重,面临的土地利用不确定性更大,需要持续性的给予重点关注。

\section{参考文献 (References) :}

[ 1 ] 曹铭昌, 刘高焕, 单凯, 侯银蓄, 王明春, 李东来, 申文明. 基于多尺度的丹顶鹤生境适宜性评价一一黄河三角洲自然保护区为例. 生 物多样性, 2010, 18(3) : 283-291.

[ 2 ] 曾颖. 生物多样性保护优先区遥感评估与区划 [D]. 杭州: 浙江大学, 2017.

[ 3 ] 孙喜娇, 张明明, Larson H, 胡灿实, 粟海军. 贵州草海越冬黑颈鹤飞出飞回夜栖地行为节律初步观察. 动物学杂志, 2018, 53(2): 180-190.

[ 4 ] 宓春荣, 郭玉民, Huettmann F, 韩雪松. 基于物种分布模型的精确采样提高目标物种发现率一以黑颈鹤 (Grus nigricollis), 白头鹤 (Grus monacha) 为例. 生态学报, 2017, 37(13): 4476-4482.

[ 5] 张会格. 黑颈鹤东部种群的迁徒路线及其停歇地研究. 北京: 中国林业科学研究院, 2007.

[ 6 ] Liu Q, Li F S, Buzzard P, Qian F W, Zhang F, Zhao J L, Yang J X, Yang X J. Migration routes and new breeding areas of black-necked cranes. The Wilson Journal of Ornithology, 2012, 124(4) : 704-712.

[ 7 ] Bishop M A, 李凤山. 农业耕作活动对西藏越冬黑颈鹤食性及食物可获得性的影响. 生物多样性, 2002, 10(4): 393-398.

[ 8 ] Dong H Y, Lu G Y, Zhong X Y, Yang X J. Winter diet and food selection of the Black-necked Crane Grus nigricollis in Dashanbao, Yunnan, China. PeerJ, 2016, 4(4): e1968.

[ 9 ] Kong D J, Luo W X, Liu Q, Li Z Q, Huan G Y, Zhang J J, Yang X J. Habitat use, preference, and utilization distribution of two crane species (Genus: Grus) in Huize National Nature Reserve, Yunnan-Guizhou Plateau, China. PeerJ, 2018, 6(7): e5105.

[10］李风山. 贵州草海越冬黑颈鹤受食栖息地选择的初步研究. 生物多样性, 1999, 7(4): 257-262.

[11] 李风山, 聂卉, 叶长虹. 黑颈鹤越冬期间植物性食物的显微分析. 动物学研究, 1997, 18(1): 51-57.

[12] Jia R, Ma T, Zhang F J, Zhang G G, Liu D P, Lu J. Population dynamics and habitat use of the Black-necked Crane (Grus nigricollis) in the Yarlung Tsangpo River basin, Tibet, China. Avian Research, 2019, 10(1): 32.

[13] 李筑眉, 李风山. 黑颈鹤研究. 上海: 上海科技教育出版社, 2005.

[14] 再景丞, 蒙文萍, 粟海军, 张明明. 草海湿地环境问题对黑颈鹤越冬影响及管理对策讨论. 野生动物学报, 2017, 38(1): 35-39.

[15] Peng W T, Kong D J, Wu C Z, Møller A P, Longcore T. Predicted effects of Chinese national park policy on wildlife habitat provisioning: experience from a plateau wetland ecosystem. Ecological Indicators, 2020, 115: 106346.

[16] 刘伶, 刘红玉, 李玉凤, 王娟, 谢富赋. 苏北地区丹顶鹤越冬种群数量及栖息地分布动态变化. 生态学报, 2018, 38(3): 926-933.

[17] 彭文娟, 董斌, 叶小康, 黄慧, 陈凌娜, 高祥. 自然湿地鹤类数量对土地利用变化的响应. 测绘科学, 2018, 43(5): 81-86.

[18］王运生, 谢丙炎, 万方浩, 肖启明, 戴良英. ROC 曲线分析在评价人侵物种分布模型中的应用. 生物多样性, 2007, 15(4): 365-372. 
[19] 陈新美, 雷洲才, 张雄清, 贾宏炎. 样本量对 MaxEnt 模型预测物种分布精度和稳定性的影响. 林业科学, 2012, 48(1) : 53-59.

[20] Hernandez P A, Graham C H, Master L L, Albert D L. The effect of sample size and species characteristics on performance of different species distribution modeling methods. Ecography, 2006, 29(5): 773-785.

[21] Engler R, Guisan A, Rechsteiner L. An improved approach for predicting the distribution of rare and endangered species from occurrence and pseudo-absence data. Journal of Applied Ecology, 2004, 41(2) : 263-274.

[22] Redpath S M, Gutiérrez R J, Wood K A, Young J C. Conflicts in Conservation: Navigating Towards Solutions. Cambridge: Cambridge University Press, 2015.

[23] Wu D W, Hu C S, Zhang M M, Li Z M, Su H J. Foraging habitat selection of overwintering Black-necked Cranes in the farming area surrounding the Caohai Wetland, Guizhou Province, China. Avian Research, 2020, 11(1): 5.

[24] 张海波, 粟海军, 刘文, 张明明, 李筑眉. 草海国家级自然保护区冬季主要水鸟群落结构与生境的关系. 生态与农村环境学报, 2014,30 (5) : 601-607.

[25] 王枋, 梁萍萍, 郝新朝, 宋善海, 张琦. 1990-2015 年贵州草海湿地国家级自然保护区景观格局演变分析. 贵州科学, 2018, 36(6)： 80-87.

[26] 吴际通, 顾卿先, 喻理飞, 谭伟. 贵州草海湿地景观格局变化分析. 西南大学学报: 自然科学版, 2014, 36(2): 28-35.

[27］高立波. 卫星跟踪黑颈鹤( Grus nigricollis) 迁徙路线以及迁徙停歇地现状初步研究. 北京: 中国林业科学研究院, 2006.

[28］国土资源部. GB/T 21010-2017 土地利用现状分类. 北京: 中国标准出版社, 2017.

[29］李凤山，马建章. 越冬黑颈鹤的时间分配、家庭和集群利益的研究. 野生动物, 1992, (3) : 36-41, 29-29.

[ 30] Sun Y W, Skidmore A K, Wang T, Van Gils H A M J, Wang Q, Qing B P, Ding C Q. Reduced dependence of Crested Ibis on winter-flooded rice fields: implications for their conservation. PLoS One, 2014, 9(5) : e98690.

[31] Ripley B D. Modelling spatial patterns. Journal of the Royal Statistical Society: Series B (Methodological), 1977, 39(2): 172-212.

[32] Diggle P J. Statistical analysis of spatial point patterns. London, UK: Academic Press, 1983.

[33] Dixon P M. Ripley's K Function//El-Shaarawi A H, Piegorsch W W, eds. Encyclopedia of Environmetrics. New York: John Wiley \& Sons, 2006 : 1796-1803.

[34] 张桐菓. 基于 GIS 的扎龙湿地丹顶鹤空间格局及其生境变化研究. 湘潭: 湖南科技大学, 2016.

[35] 操国兴, 钟章成, 刘芸, 谢德体. 缙云山川鄂连荵茶种群空间分布格局研究.生物学杂志, 2003(01) : 10- 12.

[36] Gurevitch J, Scheiner S M, Fox G A. The Ecology of Plants. Sunderland, Mass: Sinauer Associates, 2002.

[37] 楚彬, 马素洁, 周延山, 姬程鹏, 周建伟, 周睿, 田永亮, 花立民. 祁连山东段高原鼣鼠 (Eospalax baileyi)土丘空间分布格局及其与环境 因子的空间关联性. 生态学报, 2018, 38(3): 964-974.

[38] 刘强. 纳帕海越冬黑颈鹤的集群、栖息地利用和领域行为观察. 昆明: 中国科学院昆明动物研究所, 2007.

[39] Kuang F L, Li F S, Liu N, Li F Q. Effect of flock size and position in flock on vigilance of black-necked cranes (Grus nigricollis) in winter. Waterbirds Society, 2016, 37(1): 94-98.

[40］杨永霞, 白皓天, 傅伟, 彭明春, 赵子蛟, 吴太平, 苒秋月, 吴兆录. 云南大山包黑颈鹤自然保护区鸟类多样性及其与生境结构的关系. 生态学杂志, 2018, 37(1) : 147-156.

[41］王文娟, 王榄华, 侯谨谨. 人工生境已成为鄱阳湖越冬白鹤的重要受食地. 野生动物学报, 2019, 40(1)：133-137.

[42] 张明明, 张黎俊, 粟海军, 蔡静芸, 胡灿实. 草海国家级自然保护区景观格局变化与景观发展强度研究. 生态与农村环境学报, 2019, 35 (3) : 300-306.

[43] 宋涛. 威宁县马铃薯产业的发展现状分析. 耕作与栽培, 2015, (2) : 45-48. 